\title{
State Forfeiture Rules and Federal Review of State Criminal Convictions
}

\author{
R. Lea Brilmayer $\dagger$
}

The doctrines regulating federal scrutiny of state criminal convictions have undergone substantial revision in the last few years. Nonetheless, some principles seem to have remained constant. One such principle is the pattern of choice between federal and state preclusion standards on direct Supreme Court review and federal habeas corpus in cases in which federal constitutional rights have arguably been forfeited by waiver or procedural default. ${ }^{2}$ The preclusion standards at issue here are those that specify whether a federal reviewing court may address the merits of a constitutional claim not previously litigated or whether, in contrast, that claim has been "forfeited." To say that the pattern of choice has remained constant, however, is not to say that it is either simple or adequately explained in the cases or literature. On the contrary, most discussion focuses on one piece of the puzzle or another, without addressing how these jumbled pieces fit together. ${ }^{3}$ Yet

† Professor of Law, Yale Law School. Earlier versions of this paper were presented to faculty workshops at the Harvard and University of Michigan Law Schools in December 1981. The comments of the participants in those workshops, and of Frank Easterbrook, Paul Gewirtz, and John Jeffries are gratefully acknowledged. The initial idea for this article grew out of conversations with Lucinda Finley, J.D. 1980, Columbia Law School.

ISee, e.g., United States v. Frady, 102 S. Ct. 1584 (1982) (cause-and-prejudice standard for procedural defaults extends to federal prisoners and federal procedural rules, and applies even where error is plain); Engle v. Issac, $102 \mathrm{~S}$. Ct. 1558 (1982) (cause-and-prejudice test for state procedural defaults applies even to constitutional claims touching the truthfinding function of trial); Rose v. Lundy, $102 \mathrm{~S}$. Ct. 1198 (1982) (federal habeas courts must dismiss "mixed" petitions in which state remedies are not exhausted as to all claims presented); Sumner v. Mata, 449 U.S. 539 (1981) (statutory presumption of correctness applies to facts found by state appellate courts as well as trial courts, and federal habeas courts under 28 U.S.C. § 2254(d) (1976) must specify ground on record for disregarding state appellate courts' findings); Wainwright v. Sykes, 433 U.S. 72 (1977) (habeas barred where timely objection is not made in state court, unless cause for noncompliance and prejudice are shown); Stone v. Powell, 428 U.S. 465 (1976) (habeas unavailable for relitigation of fourth amendment claims).

2 Another constant, according to a recent article, is the relative lack of attention to guilt or innocence of the prisoner. Seidman, Factual Guilt and the Burger Court: An Examination of Continuity and Change in Criminal Procedure, 80 CoLum. L. Rev. 436 (1980). For further discussion of Seidman's article and disagreement with some of its points, see infra note 147.

"Articles either discuss "waiver," assuming that the applicable standard is federal, e.g., 
there are patent inconsistencies in the way that apparently similar problems are resolved.

Certain forfeitures, usually referred to as "waivers," have always been governed by federal standards on both direct and collateral federal review and in the state courts." Federal preclusion standards also determine the effect on habeas of state procedural "defaults," another category of forfeitures, despite recent Burger Court pronouncements favoring greater finality and deference to states. ${ }^{\mathbf{S}}$ At the same time, state default rules are given effect on direct review under the adequate and independent state ground doctrine, ${ }^{6}$ and ordinarily were honored even during the expansion-

Westen, Away from Waiver: A Rationale for the Forfeiture of Constitutional Rights in Criminal Procedure, 75 Mich. L. REv. 1214 (1977), or discuss the independent state ground rule on direct review or habeas, without addressing the contrast with federal waiver doctrine, e.g., Hill, The Inadequate State Ground, 65 Colum. L. Rev. 943 (1965); Sandalow, Henry v. Mississippi and the Adequate State Ground: Proposals for a Revised Doctrine, 1965 S. Cr. Rzv. 187.

- See infra notes 85-86 and accompanying text.

- See infra notes 59-68 and accompanying text.

- Although the literature and cases do not employ a completely uniform terminology, any comprehensive analysis must adopt a consistent vocabulary. I have chosen to use the term "default" rules for preclusion rules to which the adequate state ground doctrine applies. Those to which it does not apply are termed "waiver" rules. The general term for both default and waiver rules will be "forfeiture" rules. Forfeiture rules are a subset of preclusion doctrines generally, because the latter also include rules governing relitigation of claims actually raised and addressed. For example, res judicata includes both collateral estoppel of issues actually litigated, and merger and bar of issues that could have been raised. Merger and bar involve forfeiture. Relitigation rules are briefly discussed infra in the text following note 111.

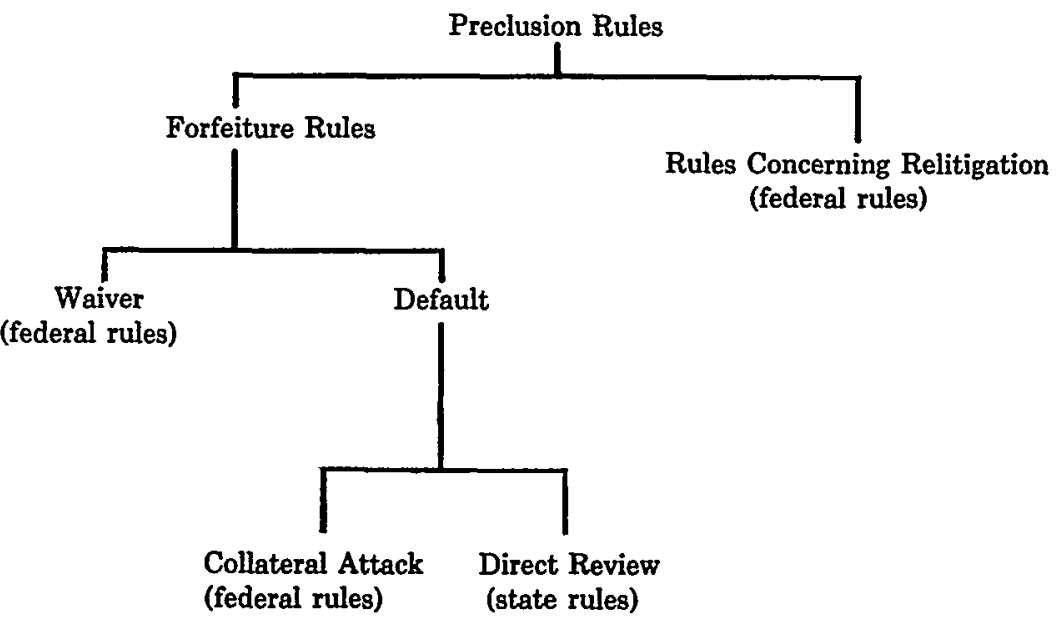

As used in this article, "waiver" covers a number of forfeitures for which different tests 
ist Warren Court era. ${ }^{7}$ States thus remain free to apply their own default rules, subject to later federal attack on habeas. The result is that both federal and state forfeiture rules can apply to the same constitutional rights. If a suspect acquiesces in an illegal search of his house, federal law determines whether he has forfeited his fourth amendment rights, but if he acquiesces in the introduction of the illegally seized evidence at trial, a state contemporaneous objection rule may work a forfeiture that will be respected on direct review, while federal forfeiture standards will once again prevail on habeas.

Why the difference? Default rules on direct review seem to be the anomaly, for the adequate state ground doctrine marks the only appearance of state rules. It turns out, however, that the most common and virtually uncontested rationale for the adequate state ground doctrine-the presumed evenhandedness of rules formulated in the context of uncontroversial application ${ }^{8}$-is in fact inapplicable, because default rules often serve only to foreclose federal constitutional claims at the expense of accused criminals and therefore cannot be presumed to be evenhanded. The reason for treating direct review differently from collateral attack is equally obscure. The need to enlist large numbers of district courts in the enforcement of federal rights may explain the desirability of using federal forfeiture standards on habeas, but it does not explain why the Supreme Court deems itself precluded from using the same federal standards on direct review." The federal habeas statute does not provide an answer because it supplies a federal preclusion standard only for already litigated questions of fact. ${ }^{10}$ Moreover,

are used. The test for waivers of Miranda rights, for example, differs from the test for waivers of rights by guilty pleas. Compare, e.g., Michigan v. Mosley, 423 U.S. 96, 104 (1975) with Tollett v. Henderson, 411 U.S. 258, 266 (1973). Similarly, there is no single test for all procedural defaults. Compare, e.g., ILL. REv. STAт. ch. 38, \& 114-1(a)(4), (b) (1981) (objections to grand jury selection must be made within a "reasonable time" after arraignment) with id. \$ 114-5(a) (motion to substitute a judge for prejudice must be made within 10 days after case is placed on judge's trial call). See also Rummel v. Estelle, 445 U.S. 263, 267 n.7 (1980) (Texas contemporaneous objection rule inapplicable to eighth amendment challenge to sentence, and claim could be heard even though first raised on habeas on petition for rehearing en banc before the Fifth Circuit Court of Appeals). What matters here is not the content of the various tests or the fact of difference, but that waivers are governed by federal law, and defaults by state law on direct review and by federal law on collateral attack.

${ }^{7}$ An exception was Henry v. Mississippi, 379 U.S. 443 (1965). See infra note 36 and accompanying text.

- See Sandalow, supra note 3, at 221.

- Denial of certiorari, after all, would transfer the case to the habeas courts as effectively as the Supreme Court's lack of jurisdiction does now.

10 See infra note 75 and accompanying text. 
no theoretical differentiation between "waiver" and "default" of federal constitutional defenses has yet been articulated that justifies using federal standards for the former but not for the latter on direct review.

A coherent theory of state forfeiture rules and federal review of state criminal convictions must therefore explain the difference between waiver and default rules, and the different functions of direct and collateral attack. Part $I$ of this article examines the three models of decisionmaking that underlie current federal scrutiny of forfeitures in state criminal cases. It then analyzes the federal practice on direct review and habeas, and explores why the usual explanations for the current pattern are inadequate. Part II offers an alternative explanation of default rules and waivers and suggests a basis for reconciling their different treatment.

\section{Present Practice: The Descriptive Thesis}

A. Possible Models of Decisionmaking

Given a sequential decisional process-first state, then federal adjudication-and a choice between state and federal forfeiture rules at each stage, four permutations are possible: each court might use federal rules, each might use state rules, each might use its own, or each might use the other's. State Court

Supremacy Model

Rendering State Model

Lex Fori Model

Reverse Lex Fori Model
Rules Used by

State Court

Rules Used by Federal Court

The three patterns found in the cases are the supremacy model, the rendering state model, and the lex fori model.

1. The supremacy model. Under the supremacy model, both courts use federal preclusion rules in determining whether to hear the defendant's constitutional claims. In situations in which it is used, it is tempting to ascribe the choice of this model to the due process clause of the fourteenth amendment, ${ }^{11}$ but in fact a due process explanation proves both too much and too little. First, it is

1 U.S. Const. amend. XIV, § 1. 
not clear why due process would supply a federal forfeiture standard instead of merely establishing a constitutional minimum that state standards must meet. Second, a due process explanation would seem to rule out the other models completely, for all state standards must satisfy due process. Yet, as will be shown below, ${ }^{12}$ these other models are sometimes evident, suggesting that many different state rules will satisfy due process. Moreover, due process limits are not unique to rules regulating the presentation of federal constitutional claims, but apply equally to preclusion of state-created rights. ${ }^{13}$ Because the federal preclusion doctrines modelled below apply only to the presentation of federal claims, a better explanation is some sort of preemption: even state preclusion rules that accord due process may be preempted if they impinge upon assertion of federal claims or defenses. ${ }^{14}$

2. The rendering state model. The rendering state model is so named to reflect the analogy to interstate enforcement of judgments. The choice of the rendering state's preclusion rule reflects respect for the prerogatives of the rendering court and makes judgments more "portable," because their effect does not vary from court to court, but vests according to the rules of the court that initially addressed the issues. ${ }^{15}$ Although the choice of the rendering court's rule elevates the first court's prerogatives and subordinates the second's, the disparity in power between the two courts is reduced in practice by doctrinal safeguards that limit the first court's ability to impose its will. The first decisionmaker seems to possess total control over the effect of its judgments in other jurisdictions, but in fact it should not be able to compel other jurisdictions to adhere to a more restrictive finality rule than it would use for its own domestic enforcement purposes. A plurality of the Supreme Court has suggested that a state cannot address interstate

12 See infra notes 26-85 and accompanying text.

1s See Central of Ga. Ry. v. Wright, 207 U.S. 127 (1907); Hill, supra note 3, at 945; Sandalow, supra note 3, at 212.

14 Cf., e.g., Dice v. Akron, C. \& Y.R.R. Co., 342 U.S. 359, 361-63 (1952) (validity of release in FELA suit); Brown v. Western Ry., 338 U.S. 294, 296, 298-99 (1949) (construction of pleadings in FELA suit); Hill, Substance and Procedure in State FELA Actions-The Converse of the Erie Problem?, 17 Oнго ST. L.J. 384 (1956).

15 See, e.g., Kremer v. Chemical Constr. Corp., 102 S. Ct. 1883, 1889 (1982) (enforcing court must give same preclusive effect as rendering court would). Although it is commonly held in the interstate enforcement context that the second court may give a judgment more credit as a matter of comity, the operative rule is nevertheless the first state's rule because it defines the extent of other states' obligations. See, e.g., Hart v. American Airlines, 61 Misc. 2d 41, 304 N.Y.S.2d 810 (Sup. Ct. 1969) (applying collateral estoppel on behalf of a nonparty to the original dispute, even though the rendering state required mutuality of estoppel and so would not have given the judgment collateral estoppel effect). 
enforcement directly, ${ }^{16}$ but only as a byproduct of formulating rules limiting its own power to reconsider. A requirement of generality and domestic applicability respects legitimate domestic interests but prevents overreaching because the first state will presumably have paused and considered carefully the consequences of restricting its own ability to relitigate.

One result of tying another jurisdiction's enforcement obligations to preclusion within the rendering state is that either both courts are free to address the problem or neither is, because both courts use the same rule. There is an identical "double or nothing" effect if both courts use a federal rule under the supremacy model. This "double or nothing" effect distinguishes these first two systems of sequential decisionmaking from the "lex fori" approach, under which the two courts use different rules. ${ }^{17}$

3. The lex fori model. As with any other lex fori approach to a choice of law, use of forum finality rules promotes forum shopping and undermines the portability of rights that might be deemed to have vested in some particular state..$^{18}$ If choosing the rendering court's rules subordinates the prerogatives of the second, letting the second court use its own rules as surely undercuts the

16 Thomas v. Washington Gas Light Co., 448 U.S. 261, 270 (1980) (a state is not authorized "by drafting or construing its legislation . . . directly to determine the extraterritorial effect of its workmen's compensation awards"). Moreover, the full faith and credit statute, 28 U.S.C. $\S 1738$ (1976), refers to the effect of a judgment in the state. The statute thus seems to require deference only to the state's domestic rules and not to its wishes about how other states should handle its judgments. Although Thomas allowed the second state to disregard a purely domestic finality policy, the best explanation for the plurality's conclusion probably lies in considerations extraneous to its disregard of extraterritorial enforcement preferences, such as the plaintiff's status as an injured workman who might have filed in the more generous state in the first place. The plurality's rejection of direct determination of extraterritorial effect, at any rate, is clear. For a brief discussion of this problem, see Brilmayer, Legitimate Interests in Multistate Problems, 79 Mich. L. REv. 1315, 1324 (1981).

17 For use of the conflict-of-laws label "lex fori," see, e.g., Ehrenzweig, A Proper Law in a Proper Forum: A "Restatement" of the "Lex Fori" Approach, 18 OKLA. L. REv. 340 (1965).

10 An ongoing controversy in academic choice-of-law circles concerns the extent to which rights "vest" in a particular state once the operative facts have occurred, or are vulnerable to post-transaction occurrences in other states. For a historical description, see generally R. Crampton, D. CuRrIE \& H. Kay, Conflict of LAws 1-7 (3d ed. 1981). Although the school of governmental interest analysis was generally hostile to arguments founded in "vested rights," see, e.g., B. CuRRIe, SkLected Essays in the Conflict of Laws 6, 50-52, 216-17 (1963), even most interest analysts balk at considering unilateral post-transaction changes in residence or otherwise impairing "settled rights and obligations." See id. at 230, 523, 737. But see Weinberg, Choice of Law and Minimal Scrutiny, 49 U. CHI. L. Rev. 440, 451 (1982) (arguing that post-transaction change in domicile can give rise to governmental interests). 
interests of the first. To minimize interference with the first court's interests and to impede forum shoppers, the second court's exercise of its superior power typically is qualified by an exhaustion requirement. ${ }^{10}$ Whether in the context of habeas, direct appellate review, or judicial review of administrative action, exhaustion requirements foreclose consideration where a remedy is still available from the first tribunal. ${ }^{20}$

The restraint manifested by exhaustion requirements is not in itself deference, however, for there is no requirement that the initial tribunal's resolution be respected. On the contrary, that resolution is respected only if the initial tribunal successfully anticipates the second's resolution. ${ }^{21}$ Exhaustion requirements protect the prerogatives of the second court, as well as those of the first court, by conserving the second court's resources for situations in which correction is necessary, with necessity defined in the second court's terms. 22

10 See, e.g., Rose v. Lundy, 102 S. Ct. 1198, 1203 (1982) (policies behind exhaustion doctrine include minimizing friction and preventing disruption of state proceedings).

${ }^{20}$ The exhaustion requirement in habeas has been recognized in cases such as $E x$ parte Royall, 117 U.S. 241 (1886), and is now a part of the statutory habeas scheme, 28 U.S.C. $\$ 2254$ (1976). In the case of appellate review, the general requirement is that orders be "final," that is, not subject to further revision by the lower court. See, e.g., Cox Broadcasting Corp. v. Cohn, 420 U.S. 469 (1975) (interpreting 28 U.S.C. § 1257 (1976)). Similarly, administrative remedies must have been exhausted before judicial intervention is proper. Myers v. Bethlehem Shipbuilding Corp., 303 U.S. 41, 50-51 (1938). See also 5 U.S.C. $\$ 704$ (1976) (only final agency action is subject to judicial review). It would be unwise to oversimplify the exhaustion requirement, which has complex exceptions, but the general thrust of the requirement in its appellate and administrative settings is clear and is analogous to its thrust in habeas. The object is to reduce forum shopping, which in the appellate hierarchy takes the form of numerous interlocutory journeys up and down the appellate ladder-" "piecemeal review." The appellate process is complicated to model because it also has aspects of the rendering state model in the independent state ground rule. Thus, in addition to an exhaustion requirement that no remedies be presently available, there may be requirements resembling exhaustion that the party have availed himself of every remedy that had ever been open. Such restrictions are discussed infra in notes 23-24 and accompanying text.

${ }^{21}$ The degree to which the initial tribunal's resolution must anticipate the second tribunal's views varies with the standard of review. If the second tribunal reviews the case de novo, the first tribunal's resolution may be entitled to no consideration at all and will be "respected" only if its resolution and the second tribunal's resolution coincide exactly. If, on the other hand, the second tribunal reviews the case under a "substantial evidence" or a "clearly erroneous" test, or for abuse of discretion, the first tribunal's resolution may be respected even if it varies from the second tribunal's inclinations. These differences in outcome, however, are the product of varying standards of review, and do not inhere in the exhaustion requirement.

12 All "avoidance techniques" are suggestive of a hierarchy. Similar doctrines include ripeness and avoidance of unnecessary constitutional questions. See, e.g., Ashwander v. TVA, 297 U.S. 288, 345-48 (1936) (Brandeis, J., concurring). Constitutional questions are to be avoided because constitutional adjudication is a scarce and important resource; "lesser" bases for decision are preferred because they are easier to reverse and do not trivialize the 
Exhaustion also should not be confused with a requirement of resort to all remedies that had ever been available. ${ }^{23}$ Although such a requirement resembles exhaustion, its effect is different. The resemblance is that in asking whether the complainant overlooked any opportunity that the first tribunal presented, the second court uses the missed opportunity as a reason for refusing to hear the challenge. The difference is that, unlike in the exhaustion setting, the missed opportunity may also preclude consideration by the first court as well. The effect is the rendering state model and its incidents-deference to the first court's rule and the double-ornothing effect. The second court cannot address the issue because the first cannot. The usual meaning of exhaustion is diametrically opposed: other decisionmakers are prohibited from stepping in because remedies are available in the rendering court. Finality according to the first court's rules is relevant, but has the opposite significance. ${ }^{24}$

The result is that under the rendering state model, qualified by the safeguard that only rules binding on the rendering state are binding on others, either two fora are available on an issue or none is, and the answer depends on the first state's rule. Under the lex fori approach, coupled with the exhaustion requirement, two fora are never available on an issue simultaneously. Whether there is even one forum on an issue depends on the second court's finality rule, and the question of which forum is determined more or less by the first court's finality rule. ${ }^{25}$ The rendering state model pro-

Constitution by casting all problems in constitutional terms.

${ }^{23}$ Fair Assessment in Real Estate Ass'n v. McNary, 102 S. Ct. 177 (1981), may provide an example of this type of "exhaustion" requirement. In that case, it was argued that there should be no remedy under 42 U.S.C. $\$ 1983$ (1976) for allegedly unconstitutional administration of a state tax system. In his concurrence, Justice Brennan reasoned that a section 1983 action was barred because the plaintiffs had not pursued administrative remedies in some years, had not appealed an adverse agency determination another year, and had a pending appeal for still another year at the time the federal court action was brought. Id. at 197. It is unclear whether any or all of these avenues of challenge were still open when the Supreme Court decided the federal case up to eight years later. The concurrence relied upon the lesser inconvenience of merely deferring, as opposed to denying, federal relief altogether. Id. at 188 n.4 (citing Louisiana Power \& Light Co. v. City of Thibodeaux, 360 U.S. 25 (1959)); id. at 196. But it seems unlikely that all were still open.

24 The irony is that two such contrary rules should both be employed ostensibly to promote the same goals of comity and recourse to the remedies of the rendering court.

${ }^{23}$ In the federal-state context, the first court's finality rule may not be entirely determinative, because the existence of further remedial process in the state court and the finality of lower court judgments are subject to federal qualifications if the lower court's acts would, for instance, merely be ministerial or if the state's collateral remedies would clearly be futile. See, e.g., Cox Broadcasting Corp. v. Cohn, 420 U.S. 469, 476-89 (1975) (discussing the federally created definition of final judgment). This qualification of the first court's rule 
tects the first state's rule about whether further proceedings on the merits are appropriate. Lex fori, coupled with exhaustion, allows the first state to specify not whether, but where, such consideration shall proceed.

\section{B. Patterns of Federal Review in State Criminal Cases}

Like any complex relationship between two decisionmaking systems, current federal practice on direct and collateral attack employs all three models outlined above, depending upon the precise question at issue.

1. Default rules on direct review: the rendering state model. On direct review of federal constitutional issues in state criminal cases, the Supreme Court honors independent and adequate state procedural grounds for the state court's result. This deference is sometimes explained in terms of the Court's constitutional duty to avoid giving advisory opinions ${ }^{28}$ and sometimes in terms of statutory limitations on its appellate jurisdiction. ${ }^{27}$ The adequate state ground rule applies to civil and criminal cases, and to substantive as well as procedural grounds. ${ }^{28}$ In criminal cases, it has been applied to state contemporaneous objection rules, ${ }^{20}$ rules regarding the timing of objections to grand jury composition, ${ }^{30}$ and rules regarding the time allowed for taking appeals. ${ }^{31}$

Of course, to bar Supreme Court review, state preclusion rules must satisfy due process: ${ }^{82}$ they must serve some rational purpose so as not to be utterly arbitrary and pointless, ${ }^{33}$ and they must allow adequate opportunity to present the claim. ${ }^{34}$ Due process problems may also arise if the rule is changed retroactively so as to foreclose all possibility of consideration. ${ }^{35}$ These due process limits have not been applied restrictively, however, and they apply even

is appropriate because the issue is governed by federal statute. See 28 U.S.C. $\S 1257$ (1976). See also Wilwording v. Swenson, 404 U.S. 249 (1971) (exhaustion not prerequisite to habeas where resort to state court would clearly be futile).

36 Herb v. Pitcairn, 324 U.S. 117, 126 (1945).

${ }^{27}$ Fay v. Noia, 372 U.S. 391, 433 (1963). See 28 U.S.C. $\S 1257$ (1976).

2* See generally P. Bator, P. Mishkin, D. Shapiro \& H. Wechsler, Hart \& Wrchsler's Tus Fedraral Courts and thz Federal System 526-74 (2d ed. 1973) [hereinafter cited as Hart \& WechsLER].

20 Herndon v. Georgia, 295 U.S. 441 (1935).

s0 Michel v. Louisiana, 350 U.S. 91 (1955).

31 Daniels v. Allen, 344 U.S. 443 (1953).

22 Reece v. Georgia, 350 U.S. 85, 88-90 (1955).

2s See Hart \& Wechsler, supra note 28, at 546; Sandalow, supra note 3, at 229 n.173.

34 Michel v. Louisiana, 350 U.S. 91, 93 (1955).

ss See Brinkerhoff-Faris Trust \& Sav. Co. v. Hill, 281 U.S. 673, 679-80 (1930). 
where the underlying claim is based upon state law.

The distinctive limitation on the state ground doctrine where the underlying claim is federal is that state default rules must have been evenly applied. ${ }^{36}$ Novel or ad hoc alterations in state procedural preclusion rules may manifest manipulation stemming from hostility to federal rights. Thus, to bar review, the state default rules must have a "fair" and "substantial" basis in existing state law. ${ }^{37}$ If state courts have power or discretion to entertain such claims despite the procedural failing, direct Supreme Court review is not barred. To bar Supreme Court review, the rule must amount to a "self-denial of power" by the state. ${ }^{38}$ Like the full-faith-andcredit rendering state model, ${ }^{38}$ the adequate state procedural ground doctrine safeguards against overreaching through a requirement of generality, ${ }^{\circ 0}$ and has the same double-or-nothing conse-

36 There were also sporadic suggestions in the cases until the 1960 's that a procedural rule might be inadequate even if it served a legitimate state interest, satisfied due process, and was evenhandedly applied. See, e.g., Douglas v. Alabama, 380 U.S. 415, 422-23 (1965); Henry v. Mississippi, 379 U.S. 443, 447 (1965); Brown v. Western Ry., 338 U.S. 294, 298-99 (1949); Davis v. Wechsler, 263 U.S. 22, 24-25 (1923).

The decision most directly relevant here is Henry, a case with prominent civil rights overtones, see Sandalow, supra note 3, at 190, in which the Court overturned a conviction based upon evidence seized after the defendant's wife gave permission to search his car. The state court held that the fourth amendment claim had been forfeited as a result of the defendant's failure to observe a state contemporaneous objection rule. The Supreme Court reversed on direct review. Hill, supra note 3 , at 988, discusses the cases cited in Henry and concludes that they did not support the Court's result. Henry's lack of precedential support, however, is less striking than its lack of generative impact. See HART \& WECHSLER, supra note 28, at 558-59; Hill, supra note 3, at 992-94. Hill dismissed Henry and like limitations on the adequate state ground rule as "spurious," $i d$. at 944, and other commentators declared it a striking departure from past law. HarT \& WECHSLER, supra note 21, at 557, 944; Sandalow, supra note 3, at 188. The Warren Court itself retreated from Henry's suggestion, 379 U.S. at 448 , that a rule was inadequate if its purposes could be substantially served in some other way, see HART \& WECHSLBR, supra note 28, at 558-59, and the Burger Court has shown no interest in reviving the project.

s7 NAACP v. Alabama, 357 U.S. 449, 454 (1958).

ss Sullivan v. Little Hunting Park, 396 U.S. 229, 234 (1969). See also Hathorn v. Lovorn, 102 S. Ct. 2421, 2426-27 (1982) (state ground must be strictly and regularly followed).

30 That the independent state ground rule is a form of preference for rendering state preclusion rules is implicitly suggested in Brilmayer, supra note 16 . The argument there was that the safeguards for choice of law should be the same as for interstate recognition of judgments. Id. at 1324. For a similar use of this terminology, see Westen, supra note 3, at 1217 (referring to state's "domestic" law of forfeiture).

${ }^{40}$ In the appellate context, rules barring initial consideration of an issue are respected while rules barring relitigation alone are not. By contrast, the federal full faith and credit statute, 28 U.S.C. $\$ 1738$ (1976), gives effect to both. In this regard, the adequate state ground doctrine differs from section 1738 , but the reasons for the difference are entirely consistent with my thesis. Rules barring relitigation are formally applicable to the lower court and the appellate court equally, but because the sequence of decisionmaking is fixed, 
quence of using the same rule in both fora. ${ }^{41}$

The usual explanation for the adequate state procedural ground doctrine relies upon these similarities to the rendering state model. In typical civil applications, procedural rules can be presumed to be fair if they are formulated to deal with noncontroversial cases that pose no federal issues. As one author has explained, " $[w]$ hen a state ground is supported by a history of consistent application, even in cases that do not involve a federal claim, it is not likely to have been used by the state court simply as a device to defeat the Court's jurisdiction."42 At the same time, exceptions to the doctrine have been made in civil rights cases in which aberrant applications of preclusion rules served to defeat constitutional defenses. ${ }^{13}$

The problem with this explanation for deference to state criminal default rules is that many fall more nearly within the exception than the rule, being narrowly drawn so as to affect only protected constitutional rights. The potential for prejudice arises because the state is party to the dispute as enforcer of its laws, and because the state knows in advance that it will never be the defendant in a criminal case and will never wish to assert the federal defense in question. The safeguard of formulation in a position of reflective neutrality is therefore absent.

Another common justification for the adequate state ground doctrine-the constitutional bar on advisory opinions ${ }^{44}$-is unconvincing if for no other reason than that the doctrine has not been applied on collateral review of defaults or on direct review of waivers, even though the prohibition against advisory opinions would be equally pertinent there. Furthermore, there seems to be nothing "advisory" about the remedy used in habeas, namely a retrial allowing the initially precluded defense. As for other limitations on

rules precluding a second look will have practical impact only on the appellate court, so that generality is no safeguard. Given that the purpose of an appellate hierarchy is relitigation, such formally "neutral" principles have no place, whereas in the full faith and credit context, the primary function is enforcement rather than relitigation. The problem of formally neutral preclusion rules is taken up again infra in notes 109-11 and accompanying text.

1 In dissent to one application of the state ground rule, Justice Black wrote that he found it "difficult to agree with the soundness of a philosophy which prompts [the Supreme] Court to grant a second review where the state has granted one but to deny any review at all where the state has granted none." Brown v. Allen, 344 U.S. 443, 554 (1953). The rule is an example of the principle that the defendant will be barred if he failed to take advantage of a remedy that was available at some time in the past. See supra note 23 and accompanying text.

12 Sandalow, supra note 3 , at 221.

43 See, e.g., Henry v. Mississippi, 379 U.S. 443 (1965), discussed supra in note 36.

14 See, e.g., Herb v. Pitcairn, 324 U.S. 117, 126 (1945). 
the Supreme Court's appellate jurisdiction, the statutory language appears inconclusive. ${ }^{40}$ The justification for foreclosing constitutional defenses under the rendering state's forfeiture rule therefore remains to be developed.

2. Default rules on collateral attack: lex fori. After expanding enormously under the Warren Court, federal collateral review of procedural defaults has contracted under the Burger Court. Throughout both periods, however, the preclusive effect on habeas of state procedural defaults has remained a question of federal standards. The content of those federal preclusion rules has changed, but the Court's adherence to the lex fori model on habeas has not.

Much of the law that governs federal habeas today is a product of the Warren Court. But the law the Warren Court inherited had already undergone significant transformations. Most important, the concept of "jurisdictional" error had expanded. The early rule was that habeas might be granted only where the convicting court lacked jurisdiction. ${ }^{48}$ The definition of jurisdictional error, however, was federal and did not refer to state provision for collateral attack. ${ }^{47}$ Over time, the requirement of jurisdictional error was diluted beyond recognition and possibly also beyond analytical salvation. ${ }^{48}$ Brown $v$. Allen, ${ }^{49}$ decided in 1953 , the transition year to the Warren Court, abandoned the jurisdictional rubric and subjected even jurisdictionally sound convictions to federal collateral attack.

Brown thus left the federal courts with a blank slate upon which to write a new set of federal preclusion rules, and Warren Court cases began to supply them. Townsend $v$. Sain ${ }^{50}$ established criteria for district courts to use in deciding whether to take new evidence on disputed factual issues or to defer to the state courts'

45 See 28 U.S.C. $\$ 1257$ (1976). The statutory explanation of the adequate state ground rule is criticized in Sandalow, supra note 3 , at 233 n.187.

4s See, e.g., Bergemann v. Backer, 157 U.S. 655 (1895); Andrews v. Swartz, 156 U.S. 272 (1895). See also Frank v. Mangum, 237 U.S. 309 (1915).

47 Most of the pre-Warren Court opinions on jurisdictional error were written before Erie R.R. Co. v. Tompkins, 304 U.S. 64 (1938), so it is not surprising that they did not discuss the source of the res judicata principles they employed. Given the exhaustion requirement, however, the cases necessarily were using federal principles; otherwise, if the state allowed collateral attack, the prisoner would have been required to exhaust state remedies first.

48 The historical development is discussed in HART \& WECHSLER, supra note 28, at 1465-72, and in Bator, Finality in Criminal Law and Federal Habeas Corpus for State Prisoners, 76 HaRv. L. REv. 441, 463-99 (1963).

to 344 U.S. 433 (1953).

so 372 U.S. 293 (1963). 
resolutions. The problem in Townsend was the voluntariness of a confession, and the Court held that an evidentiary hearing was required "unless the state-court trier of fact has after a full hearing reliably found the relevant facts." The criteria included whether the material facts were developed at the state court hearing, whether there were allegations of newly discovered evidence, whether the merits were explicitly addressed, and whether the factual determinations were supported by the record as a whole..$^{52}$ These criteria are now part of the federal habeas statute. ${ }^{53}$

In Fay v. Noia, ${ }^{\text {st }}$ decided during the same term as Townsend, the Court abolished the adequate state procedural ground rule on collateral attack. Adopting Professor Hart's interpretation, ${ }^{\text {ss }}$ the Court held that exhaustion referred only to remedies still available at the time that federal relief was sought. ${ }^{68}$ To the Court, the penalty of forever losing a meritorious constitutional defense was unnecessarily severe for disobedience of a state procedural rule; the loss of a claim on direct review was deemed adequate disincentive. ${ }^{57}$ The Court further created a new-and needless to say federal-standard of deliberate bypass for determining whether failure to observe procedural rules should result in preclusion on habeas. This standard was expected to be broad enough to deal with calculated strategic choices to circumvent state procedures..$^{\text {ss }}$

The Burger Court's continuation of federal preclusion rules on habeas is less obvious. Even a casual glance through recent Supreme Court decisions reveals an increasing willingness to leave matters to the states, and the cases abound with complimentary references to the state courts' expertise in interpreting and applying the Constitution. ${ }^{\mathrm{s}}$ Deference to state interests plays an ever more important part in the opinions, along with comity and minimization of interjurisdictional friction. ${ }^{60}$ With respect to procedu-

s1 Id. at 313 (footnote omitted).

12 Id.

s3 28 U.S.C. \& 2254(d) (1976).

372 U.S. 391 (1963).

ss Hart, Foreword: The Time Chart of the Justices, 73 Harv. L. REv. 84, 112 (1959). See HaRT \& WrChSLER, supra note 28 , at 1482 \& n.2.

so 372 U.S. at $434-35$.

${ }^{87}$ Id. at 431-34. For a comparison of this reasoning to the Burger Court's reasoning in Stone $v$. Powell, see infra notes $135-48$ and accompanying text.

sa 372 U.S. at 438-39.

s* See, e.g., Allen v. McCurry, 449 U.S. 90, 105 (1980); Stone v. Powell, 428 U.S. 465, 493-94 n.35 (1976).

-o See, e.g., Sumner v. Mata, 449 U.S. 539, 550 (1981); Allen v. McCurry, 449 U.S. 90, 95-96 (1980); Francis v. Henderson, 425 U.S. 536, 539 (1976). 
ral defaults, a number of cases seem to defer to state court finality doctrine and to rely on state preclusion rules. In Allen v. McCurry, ${ }^{61}$ for example, the Supreme Court held that collateral estoppel and the federal full faith and credit statute ${ }^{62}$ precluded a section 1983 action for damages for an allegedly unconstitutional search because of findings at the earlier state criminal trial. In Stone v. Powell, ${ }^{63}$ the Court barred relitigation of fourth amendment claims on habeas, rejecting the argument that state courts would not be fair and competent fora for the adjudication of federal constitutional rights. In Francis $v$. Henderson, ${ }^{64}$ the Court essentially gave effect on habeas to a state contemporaneous objection requirement and denied the defendant's challenge to the racial composition of the grand jury that indicted him.

The most convincing evidence of a trend toward reliance upon state finality rules is Wainwright $v$. Sykes, ${ }^{88}$ which seemed to revive the pre-Fay deference on habeas to state procedural grounds. The defendant in Wainwright raised a Miranda claim for the first time in the course of post-conviction proceedings, even though a state procedural rule required such objections to be made before or during the trial. The Supreme Court held that the state's contemporaneous objection rule barred consideration in a post-conviction attack, noting that the rule served valid procedural purposes. ${ }^{86}$ The dissent objected that the majority opinion "would essentially leave it to the States, through the enactment of procedure . . . to determine whether a habeas applicant will be permitted the access to the federal forum that is guaranteed him by Congress." dissent also protested the double-or-nothing effect of allowing procedural defaults to bar habeas review, ${ }^{88}$ an effect that is a familiar consequence of using the first tribunal's preclusion rules.

Notwithstanding these indications of deference in recent cases, the Burger Court has not abandoned the lex fori pattern on habeas in favor of the rendering state model; it has merely altered the

61 449 U.S. 90 (1980).

62 28 U.S.C. \& 1738 (1976).

os 428 U.S. $465,493-94$ n.35 (1976).

o4 425 U.S. 536,541 (1975).

es 433 U.S. 72 (1977).

Id. at 88-90.

67 Id. at 107 (Brennan, J., dissenting) (footnote omitted).

68 Id. at 108 (Brennan, J., dissenting) ("From the standpoint of the habeas petitioner, it is a harsh rule indeed that denies him 'any review at all where the state has granted none'-particularly when he would have enjoyed both state and federal consideration had his attorney not erred.") (citing Brown v. Allen, 344 U.S. 443, 552 (1953) (Black, J., dissenting)). 
content of the governing federal preclusion rules. In Francis $v$. Henderson, for example, preclusion was held to be proper only because the state contemporaneous objection rule resembled the federal rule. ${ }^{69}$ Moreover, each of these instances of deference to state decisionmaking power is qualified by federal exceptions. Stone $v$. Powell cited no state authority in denying relitigation of fourth amendment claims where the state has provided a "full and fair opportunity" for litigation in the first instance; instead, it cited Townsend $v$. Sain, a case decided on the basis of federal preclusion law. ${ }^{70}$ Wainwright replaced the "deliberate bypass" standard of Fay v. Noia not with a state standard, but with a new federal standard permitting federal consideration of the claim if "cause and prejudice" were shown. ${ }^{71}$ That this was a federal exception is clear from the fact that the Court did not cite any state-created exception to the contemporaneous objection rule. Further, both majority and dissent contemplated further Supreme Court exegesis to clarify the meanings of the terms. ${ }^{72}$

Although the lex fori pattern is clear, the most obvious explanations for its adoption by habeas courts to judge the preclusive effect of procedural defaults turn out to be unsatisfactory. The readiest explanation is based on 28 U.S.C. $\S 2254$, the statutory codification of the Townsend criteria, which dictates a federal finality rule and could explain why habeas courts are not obliged to heed the apparent statutory command of section $1738^{73}$ to apply state finality rules. Indeed, the Supreme Court has recently suggested in dicta that this is the reason section 1738 does not apply

625 U.S. at $541-42$.

to 428 U.S. at 494 (citing Townsend v. Sain, 372 U.S. 293 (1963)). See supra note 50 and accompanying text. The Court in a recent decision has suggested that the "full and fair opportunity" exception may be no more than the due process minimum for preclusive effect. Kremer v. Chemical Constr. Corp., $102 \mathrm{~S}$. Ct. 1883 (1982). Its discussion of the meaning given the phrase as it was used in Allen v. McCurry, 449 U.S. 90, 101 (1980), is neither convincing nor particularly relevant here. If Stone relied upon Townsend, the phrase surely requires more than due process, for Townsend was not founded upon due process, but established a more stringent standard. Also, Kremer's due process characterization of Allen is unsound insofar as Allen relied on Parklane Hosiery Co. v. Shore, 439 U.S. 322 (1979), which was not a due process holding, but instead purported to develop federal preclusion principles concerning offensive use of nonmutual collateral estoppel. Kremer did not cite Stone, and it is unclear what its relevance will be for habeas, particularly because it indicated that 28 U.S.C. $\$ 2254$ was an exception to section 1738 . $102 \mathrm{~S}$. Ct. at 1899 n.27.

71433 U.S. at 87 . The formula was taken from Francis v. Henderson, 425 U.S. 536, 542 (1976), and United States v. Davis, 411 U.S. 233, 242, 244-45 (1973).

${ }^{72} 433$ U.S. at 87 ("We leave open for resolution in future decisions the precise definition of the 'cause' and 'prejudice' standard . . . ."); id. at 116-17 (Brennan, J., dissenting) (objecting to unclearness of the standard).

7328 U.S.C. $\$ 1738$ (1976). 
on habeas. ${ }^{74}$ Setting aside the fact that section 2254 merely enacted judicially created rules, there is a serious problem in that it covers only questions of fact, not questions of law or mixed questions of law and fact, or defenses that were never litigated because arguably forfeited. ${ }^{75}$ Due process and preemption alone are also inadequate explanations, because they would apply equally to direct review and would apparently also require the states to apply the federal rules in their own courts. That would entail the supremacy and not the lex fori approach. ${ }^{76}$

Other explanations might rely upon the fact that criminal incarceration implicates unusually compelling policies in favor of relitigation. First, criminal sentences are continuing orders, and continuing orders are usually more readily modifiable than other judgments because they do not give rise to vested rights. ${ }^{77}$ Second, states arguably do not acquire vested rights in wrongful convictions because they have an independent interest in seeing justice

${ }^{74}$ Kremer v. Chemical Constr. Corp., 102 S. Ct. 1883, 1899 n.27 (1982).

${ }^{76}$ Sumner v. Mata, 449 U.S. 539, 555 (1981) (citing Brewer v. Williams, 430 U.S. 387, 403-04 (1977)). See Halpern, Federal Habeas Corpus and the Mapp Exclusionary Rule After Stone v. Powell, 82 Colum. L. Rev. 1, 15 (1982).

${ }^{78}$ See supra notes 11-14 and accompanying text.

77 For instance, continuing injunctions are modifiable orders. United States v. Swift \& Co., 286 U.S. 106, 114 (1932); Pennsylvania v. Wheeling \& Belmont Bridge Co., 59 U.S. (18 How.) 421, 431-32 (1857); Developments in the Law-Injunctions, 78 HARv. L. REv. 994, 1081 (1965); Annot., A.L.R. 765 (1942).

Generally, orders in ongoing controversies are entitled to less recognition than orders regarding purely past occurrences. See, e.g., Thomas v. Washington Gas Light Co., 448 U.S. 261 (1980), in which the Supreme Court refused to require recognition of a workmen's compensation award. See also Commissioner v. Sunnen, 333 U.S. 591, 599 (1948) (collateral estoppel inapplicable when there has been a change in the controlling legal principles). $C f$. Wooley v. Maynard, 430 U.S. 705, 711 (1977) (jurisdiction is not barred by Younger v. Harris, 401 U.S. 37 (1971), where the defendant seeks only to be free from prosecutions for future violations of the same statutes). But see Federated Dep't Stores v. Moitie, 452 U.S. 394, 399 (1981) (res judicata barred relitigation by plaintiffs of an unappealed adverse judgment even though other plaintiffs in similar actions successfully appealed judgments against them); Montana v. United States, 440 U.S. 147, 161 (1979) (collateral estoppel bars relitigation unless there has been a change in facts "essential" to the previous judgment or there have been "major" changes in the controlling law); Yarborough v. Yarborough, 290 U.S. 202 (1933) (collateral estoppel applied despite a continuing relationship and the creation of a new interest); United States v. Moser, 266 U.S. 236, 242 (1924) (collateral estoppel barred relitigation even though the law was erroneously applied in the first case).

The existence of a continuing controversy is important in habeas because moot issues will not be addressed, a limitation reflected in the requirement of continuing "custody." See, e.g., Carafas v. LaVallee, 391 U.S. 234 (1968); Jones v. Cunningham, 371 U.S. 236 (1963); Hart \& WechsLer, supra note 28, at 1507-10. Habeas also does not lie where the only sanction is a fine. See, e.g., Hanson v. Circuit Court of the First Judicial Circuit, 591 F.2d 404, 407 (7th Cir. 1979). 
done. ${ }^{78}$ Third, because criminal defendants often come from disadvantaged backgrounds and are often represented by overworked and undercompensated court-appointed counsel, they arguably should not be held to the same rigorous procedural standards as ordinary civil defendants. ${ }^{79}$ Finally, custody is a uniquely serious sanction. Incarceration is an inappropriate sanction for procedural default, yet it may well be the consequence of foreclosing constitutional arguments for failure to comply with state procedural regulations. Moreover, procedural default rules result in arbitrary distinctions between cases identical on the merits. ${ }^{80}$

The problem is that even to the extent these arguments are persuasive, they do not dictate which decisionmaker should formulate preclusion rules to take them into account. The argument would seem to be that substantive policies favoring relitigation compel the lex fori approach, but in child custody cases, a somewhat analogous civil problem implicating many of the same policies, $^{81}$ the rendering state model of section 1738 has been assumed

78 See, e.g., United States v. Agurs, 427 U.S. 97, 111 (1976) (citing Berger v. United States, 295 U.S. 78, 88 (1935)) (prosecutor is the "servant of the law, the twofold aim of which is that guilt shall not escape or innocence suffer"); Linkletter v. Walker, 381 U.S. 618, 652 (1965) (Black, J., dissenting) ("No state should be considered to have a vested interest in keeping prisoners in jail who were convicted because of lawless conduct by the State's officials."); Fay v. Noia, 372 U.S. 391, 441 (1963) ("Surely no fair-minded person will be content that those who have been deprived of their liberty without due process of law ought nevertheless to languish in prison."). But see Westen, supra note 3, at 1230 (discussing critically the theory that prosecutors acquire no rights in erroneous convictions).

70 See, e.g., Miranda v. Arizona, 384 U.S. 436, 457 (1966); Seidman, supra note 2, at 501 (criminal defendants are often inarticulate and targets of prejudice). See also Gagnon v. Scarpelli, 411 U.S. 778, 786-87 (1972); Powell v. Alabama, 287 U.S. 45, 69 (1932); Cover \& Aleinkoff, Dialectical Federalism: Habeas Corpus and the Court, 86 YaLe L.J. 1035, 1037 (1977) (citing Rinaldi v. Yeager, 384 U.S. 305 (1966); Douglas v. California, 372 U.S. 353 (1963); and Griffin v. Illinois, 351 U.S. 12 (1956)); Israel, Criminal Procedure, the Burger Court, and the Legacy of the Warren Court, 75 Mich. L. REv, 1320, 1331-34 (1977); Seidman, supra note 2, at 442 n.33. Cf. R. Crampton, D. Currie \& H. Kay, Conflict of Laws 678 (2d ed. 1975) (fact that injured workmen are a necessitous class may explain relitigation of workmen's compensation awards).

so See Fay v. Noia, 372 U.S. 391, 441 (1963) ("[S]urely no just and humane legal system can tolerate a result whereby [two codefendants] are at liberty because their confessions were found to have been coerced yet a [third codefendant], whose confession was also coerced, remains in jail for life."). Cf. Linkletter v. Walker, 381 U.S. 618, 642 (1965) (Black, J., dissenting) (prospective application of constitutional holding as unfair and invidious discrimination).

s1 Child custody awards are continuing orders and thus are subject to modification in most states. H. Clark, The Law of Domestic Relations in the United States $§ 17.7$ (1968). The prevailing parent does not acquire a vested right in the outcome because a truly competent parent only wishes a resolution in the child's best interests. See Minow, The Judgment of Solomon and the Experience of Justice, in The Structure of Procedure 447 (R. Cover \& O. Fiss eds. 1979); Mnookin, Child-Custody Adjudication: Judicial Functions 
to apply. Recent federal legislative reform dealing with child custody has reaffirmed this commitment to the rendering state approach. ${ }^{82}$ As the history of child custody finality doctrine suggests, a changing assessment of the importance of finality need not result in changing one's finality model. In fact, if it did, one would expect that the Burger Court's disillusionment with relitigation would have resulted in a direct application of the state's own rules. The question therefore remains why a Supreme Court ostensibly interested in promoting stability of decisions and reducing interjurisdictional friction would not turn to the rendering state approach on habeas.

The reason for the survival of lex fori on habeas may be a cynical or subliminal desire to preserve federal judicial power. This calculating approach is suggested by the Court's phrasing of the cases in terms of comity, and by its disinclination to explain its deferential stance in terms of a lack of jurisdiction or power, ${ }^{83}$ even

in the Face of Indeterminacy, 39 LAw \& ConTEmp. ProBs. 226, 229, 251 (Summer 1975) (distinguishing courts' traditional adversarial dispute settlement function from the child protection function of custody decisions). Moreover, children are not accountable for litigation mistakes-less accountable than criminal defendants. See Ford v. Ford, 371 U.S. 187 (1962). For a discussion of the potential divergence of interests between wards and their custodians, see Garvey, Freedom and Choice in Constitutional Law, 94 HARv. L. REv. 1756, 1778-81 (1981). See also Lehman v. Lycoming County Children's Servs. Agency, 648 F.2d 135, 152-55 (3d Cir. 1981) (en banc) (Adams, J., concurring), aff'd, 102 S. Ct. 3221 (1982). Finally, the general prohibition against using an award as a sanction against recalcitrant parents shows that child custody should not be determined on the basis of procedural default. See, e.g., Bodenheimer, Progress Under the Uniform Child Custody Jurisdiction Act and Remaining Problems: Punitive Decrees, Joint Custody, and Excessive Modifications, 65 CaLIF. L. REv. 978, 1006-07 (1977); see also Berlin v. Berlin, 21 N.Y.2d 371, 377-78, 235 N.E.2d 109, 112-13, 288 N.Y.S.2d 44, 49-50 (1967), cert. denied, 393 U.S. 840 (1968).

${ }^{82}$ See 28 U.S.C.A. $\$ 1738$ A (West Supp. 1982). The general impact of the section is to require that modification requests be addressed to the rendering state. Prior history of the statute is discussed in Coombs, The "Snatched" Child is Halfway Home in Congress, 11 FAM. L.Q. 407 (1978), and Shutter, Parental Kidnapping Prevention Act-Panacea or Toothless Tiger?, FuA. B.J. 479, 480 (1981). See generally R. CRouch, IntERstate Custody Litigation (1981); S. Katz, Child Snatching: The Legal Response to the Abduction of CHLDREN (1981); Bodenheimer, The Rights of Children and the Crisis in Custody Litigation: Modification of Custody in and out of State, 46 U. CoLo. L. REv. 495 (1975). See also Lehman v. Lycoming County Children's Servs. Agency, 102 S. Ct. 3231, 3239-40 (1982) (involuntary termination of parental rights does not involve custody within meaning of federal habeas statute).

ss See, e.g., Wainwright v. Sykes, 433 U.S. 72, 88 (1977) (state contemporaneous objection rule not jurisdictional, but deserves respect in part because "it is employed by a coordinate jurisdiction within the federal system"); Stone v. Powell, 428 U.S. 465, 495 n.37 (1976) (decision "does not mean that the federal court lacks jurisdiction" on habeas over fourth amendment claims decided in a state trial); Francis v. Henderson, 425 U.S. 536, 539 (1976) ("II]n some circumstances considerations of comity and concerns for the orderly administration of criminal justice require a federal court to forgo exercise of its habeas corpus power."). Compare Justice Harlan's dissent, phrased in terms of jurisdiction and power, in 
though the issue of ability to relitigate has been so framed when it is to the Court's advantage. ${ }^{84}$ Yet a Court seeking to enlarge federal power would be unlikely to feel bound by state default rules on direct review, as the Court now feels under the adequate state ground doctrine. Moreover, the Court has only been selective and not entirely oblivious toward state preclusion law on direct and collateral review of state criminal cases. This is not to say that the Court's use of federal preclusion rules on habeas is wrong or necessarily inconsistent with its deference to state default rules on direct review; it is merely insufficiently explained. Before an explanation of the Court's treatment of state default rules can be attempted, however, it is necessary to address the Court's treatment of waivers, in which another preclusion model is applied-supremacy.

3. Waiver rules: supremacy. Many preclusion rules-most notably those analyzed in the cases under the rubric "waiver" - follow a pattern virtually opposite to the one that governs default rules. ${ }^{85}$ Whereas state courts are free to apply their own definitions of procedural default to federal rights and defenses, subject only to scrutiny for consistency with due process and evenhanded application on direct review and to relitigation under federal preclusion standards on habeas, state courts are generally not free at any point to apply their own definitions of waiver when federal rights are at issue. The operative model here is supremacy: on both direct and collateral attack, and in the state courts themselves, federal standards determine when federal defenses may be deemed waived. $^{\text {s8 }}$

Fay v. Noia, 372 U.S. 391, 463-70 (1963).

st See, e.g., Sumner v. Mata, 449 U.S. 539, 547 n.2 (1981) (issue involving interpretation of 28 U.S.C. $\$ 2254$ (d) (1976) may be raised for the first time on appeal because it is "jurisdictional").

ss It should be remembered that not all the cases treated here under the rubric "waiver" actually use the term, and not all employ the same test of preclusion, but all apply federal rather than state standards. This federal element distinguishes the rules treated here as "waivers" from the rules discussed above as "defaults." See supra note 6.

st States may attach less preclusive effect to an act of waiver than federal standards attach, but they may not attach more. Lefkowitz v. Newsome, 420 U.S. 283 (1975) (habeas), and Sibron v. New York, 392 U.S. 40 (1968) (direct review), illustrate this principle. Both cases permitted federal relitigation of fourth amendment claims that were unsuccessful at trial and were arguably barred by guilty pleas. Under federal law, a guilty plea ordinarily forecloses consideration of suppression claims; however, New York had a law allowing defendants to plead guilty, yet preserve their suppression claims for appeal. The Supreme Court followed the state rule. See Lefkowitz v. Newsome, 420 U.S. at 293; Sibron v. New York, 392 U.S. at $45 \&$ n.2. Dissenting opinions in Newsome argued that the preclusive effect of a guilty plea is always a question of federal law and that the suppression claim was therefore 
Most of these federal waiver rules deal with the steps a defendant must take to preserve conceded constitutional rights. ${ }^{87}$ For example, he may waive his fifth amendment right to remain silent under police interrogation by voluntarily answering questions or confessing after having been read his Miranda rights. ${ }^{88}$ If he allows the police to search his house or automobile, he may be waiving his rights under the fourth amendment. ${ }^{88}$ His sixth amendment right to be present and to confront witnesses at trial may be lost through obstreperous behavior in court..$^{90}$ Virtually every right he has will be deemed waived if he does not insist on a trial but instead pleads guilty. ${ }^{91}$

waived. 420 U.S. at 296-98 (White, J., dissenting); id. at 303 (Powell, J., dissenting). The majority, however, apparently viewed the federal standard as permitting but not establishing a waiver, and held that because state law allowed preservation of the claim, it survived the guilty plea and could be considered on habeas, $i d$. at 293 , or on direct review, id. at 290 n.6.

In one respect, the adequate state ground doctrine is similar to the doctrine of Lefkowitz $v$. Newsome. If the state had argued in Newsome that as a matter of state statutory interpretation federal habeas scrutiny was excluded, the majority presumably would have responded that ad hoc manipulation of state law cannot be allowed to defeat federal consideration of federal constitutional claims. As in the state ground context, if the state court is able to address the claim, the federal court is able also. See supra note 38 and accompanying text. In other respects, however, the two doctrines are quite different. Federal courts only defer to state waiver doctrines that are less preclusive than federal standards, whereas state procedural default rules are typically more preclusive than the federal standards applied on habeas. Thus, the effect of deference in Newsome was not to foreclose but to preserve a federal claim.

87 An interesting counterexample is the federal harmless error rule, recognized in Chapman v. California, 386 U.S. 18, 21 (1967).

${ }^{88}$ Fare v. Michael C., 442 U.S. 707, 724-25 (1979); North Carolina v. Butler, 441 U.S. 369, 373 (1979); Michigan v. Mosley, 423 U.S. 96, 104 (1975).

${ }^{89}$ United States v. Watson, 423 U.S. 411, 424 (1976); Schneckloth v. Bustamonte, 412 U.S. 218, 227 (1973); United States v. Wasserteil, 641 F.2d 704, 707 (9th Cir. 1981); United States v. O'Looney, 544 F.2d 385, 388 (9th Cir.), cert. denied, 429 U.S. 1023 (1976).

${ }^{\circ 0}$ E.g., Illinois v. Allen, 397 U.S. 337, 343 (1970).

21 The constitutionality of guilty pleas was settled by the so-called "Brady trilogy"-Brady v. United States, 397 U.S. 742 (1970); McMann v. Richardson, 397 U.S. 759 (1970); Parker v. North Carolina, 397 U.S. 790 (1970). Some rights are apparently not forfeited by pleading guilty, such as the right not to be tried a second time, Menna v. New York, 423 U.S. 61, 62 (1975); Blackledge v. Perry, 417 U.S. 21, 29-31 (1974), and possibly also the right not to be charged under an unconstitutional statute. See Alschuler, The Supreme Court, the Defense Attorney, and the Guilty Plea, 47 U. CoLo. L. REv. 1, 17-21 (1975); Westen, supra note 3, at 1225 n.28. Lower courts have placed the right to a speedy trial in this category. See Westen, supra note 3, at 1224 n.26 (collecting cases). Westen has puzzled over why such "incurable" defects cannot be waived, while curable ones can. He finds an answer in the state's reliance interest in cases that could have gone to trial but are now too stale to prosecute. Id. at 1237. Another explanation might be that if, as Blackledge suggested, 417 U.S. at 31 , a defendant cannot waive a right preventing the state from trying him at all, it is because the consideration that is normally received for pleading guilty does not exist. Ordinarily, the defendant receives a benefit in that the state does not try him to 
Although the literature on waiver is extensive and stimulating, ${ }^{92}$ neither the commentary nor the cases have satisfactorily addressed the relationship between waiver and state procedural default. Both seem to involve the steps that must be taken to preserve or present federal constitutional claims. The problem is especially apparent in cases in which both types of forfeiture are present-where the assertion of a federal right is arguably barred by both waiver and a later procedural default..s

Henry v. Mississippi ${ }^{94}$ illustrates the problem. There were two forfeiture issues in Henry, a waiver and a default. First, Henry's wife arguably had waived his right not to have his car searched.95 Second, Henry arguably had forfeited his right to challenge the "waiver" and to object to the introduction of the evidence by defaulting on a state contemporaneous objection rule. ${ }^{98}$ The Supreme Court assumed that Henry's procedural default could be ignored on collateral attack, so that a federal habeas court could reach the merits of his waiver claim. ${ }^{27}$ This follows the usual lex fori approach on habeas. The waiver claim itself was deemed at all points to be a matter of federal law; no amount of state law defining the requirements for preserving fourth amendment rights would have deflected federal scrutiny. ${ }^{98}$ The operative model was supremacy. The Court, however, held that a federal standard also governed the preclusive effect of Henry's procedural default on direct attack,

the full extent of criminal penalties, but settles for a lesser penalty. As in contract law, there is a difference between consideration that turns out to be worthless (the defendant would have prevailed had he gone to trial) and consideration that does not exist (the state bargained a right to try the defendant that it did not own in the first place).

22 In addition to Westen, supra note 3, and Alschuler, supra note 91, see Hill, The Forfeiture of Constitutional Rights in Criminal Cases, 78 Cotum. L. REv. 1050 (1978); Rosenberg, Jettisoning Fay v. Noia: Procedural Defaults by Reasonably Incompetent Counsel, 62 Minn. L. REv. 341 (1978); Seidman, supra note 2; Spritzer, Criminal Waiver, Procedural Default and the Burger Court, 126 U. PA. L. REv. 473 (1978); Tigar, Foreword: Waiver of Constitutional Rights: Disquiet in the Citadel, 84 Harv. L. Rev. 1 (1970).

is As Justice Brennan wrote in dissent in Francis $v$. Henderson, a procedural default case:

[T]he Court has never fully addressed the constitutional dimensions of the waiver problem. "Waiver affecting federal rights is a federal question." . . . If, as a matter of constitutional law, a substantive constitutional right . . . may not be lost unless it has been knowingly and intelligently waived . . ., it is difficult to fathom how the existence vel non of a state procedural rule that a claim to that right must be asserted at a particular time can in any way dilute that constitutional waiver standard.

425 U.S. 536, $548 \mathrm{n} .2$ (1976) (citations omitted).

379 U.S. 443 (1965).

os Id. at 444-45.

or Id. at 445-46.

7 Id. at 452.

se See id. at 452-53. 
apparently rejecting the usual rendering state approach. This departure from the adequate state ground doctrine was much criticized, and the Court later retreated from this part of the opinion.99 What is puzzling is why the federal forfeiture standard for waivers was not equally controversial; it passed unnoticed and survives unscathed.

The immediately obvious distinctions are unavailing. Although the waiver occurred before trial while the default occurred at trial, the distinguishing principle is not timing, for in other cases the sequence was reversed: Michel $v$. Louisiana ${ }^{100}$ involved pretrial default and Illinois $v$. Allen ${ }^{101}$ involved waiver at trial. Nor is generality the distinguishing principle: although waivers often involve case-by-case determinations while defaults often involve blackletter rules, default rules may also be based upon lines of judicial precedent, ${ }^{102}$ and it is hard to believe that any federal waiver case would have been resolved differently if the state had enacted its waiver principle by legislation. ${ }^{103}$ Besides, if the problem addressed by federal waiver standards were manipulative, ad hoc decisionmaking, separate federal rules for waivers would be unnecessary, because the adequate state ground doctrine already requires that state forfeiture rules be evenhandedly applied.

Another possible explanation for the different treatment of defaults and waivers on direct review is that waivers present procedural due process problems while defaults do not. The cases lend some support to this theory, for waiver cases are occasionally framed in due process terms ${ }^{104}$ while default cases generally are not. In addition, this theory would explain why the Supreme Court defers to defaults but not waivers on direct review, for state waiver law that is inconsistent with due process obviously cannot prevent Supreme Court review and must be subjected to federal scrutiny. The problems with this explanation have already been noted:105

92 See supra note 36 .

${ }^{100} 350$ U.S. 91 (1955) (state rule required objection to grand jury composition to be made before trial).

101397 U.S. 337 (1970) (defendant's misconduct during trial resulted in loss of right to be present at trial).

${ }^{102}$ This is the main reason that allegations of impermissible manipulation can be made with respect to state procedural default rules. See supra notes $36-37$ and accompanying text.

${ }^{103}$ For instance, all 50 states have harmless error statutes, yet these were supplanted by a federal harmless error rule in Chapman v. California, 386 U.S. 18, 21-22 (1967).

${ }^{104}$ See, e.g., Boykin v. Alabama, 395 U.S. 238, 243 n.5 (1968); McCarthy v. United States, 394 U.S. 459, 466 (1968); Rice v. Olson, 324 U.S. 786, 787 (1945).

${ }^{105}$ See supra text accompanying note 11. 
due process considerations should be equally pertinent to ostensibly adequate state grounds, and due process by itself will not explain why federal waiver law is required for federal claims but not state claims.

A better explanation than due process is preemption, for state courts are themselves obliged to use the federal waiver standard in deciding waivers of federal claims. But "preemption" merely restates the original question: why are state waiver rules preempted from application to federal rights while state procedural default rules are not?

\section{The Explanatory Thesis}

\section{A. Inferences from Structure}

As a matter of structural analysis, there are two reasons for involving a second court in a decision that has already been made: enforcement and review. ${ }^{108}$ The full faith and credit clause ${ }^{107}$ and its implementing statute ${ }^{108}$ address enforcement by requiring intersystemic cooperation and respect for judgments. Other judicially created comity principles also distinguish between enforcement and review by providing that losing litigants seeking only critical scrutiny may not apply to another tribunal, but must direct their complaints to the rendering court. ${ }^{109}$ Attack in another forum is not supposed to substitute for an appeal; objection may only be made as a defense when the prevailing party invokes some other tribunal's enforcement power. ${ }^{110}$ Appellate scrutiny is different

106 Normative inferences about the proper functioning of systems can sometimes be drawn from the way those systems were set up. See C. Black, StructurB AND RBLATIONShIP in Constitutional Law 3-32 (1969). Given their structure, there may be only one possible intended use. Basic principles about the likely purposes of sequential decisionmaking support such inferences concerning the choice between federal and state finality rules on federal habeas corpus. The analogous structural inference regarding appellate systems illustrates how inferences regarding habeas corpus may be drawn.

${ }_{107}$ U.S. CoNST. art. IV, $\$ 1$.

10828 U.S.C. § 1738 (1976).

100 The reasons given include comity, orderly administration of justice, and prevention of forum shopping. See, e.g., Commercial Union of Am., Inc. v. Anglo-S. Am. Bank, 10 F.2d 937, 940 (2d Cir. 1925); Marshall Field \& Co. v. Nyman, 285 Il. 306, 308, 120 N.E. 756, 757 (1918); Missouri Pac. Ry. v. Lasca, 79 Kan. 311, 320, 99 P. 616, 619 (1909); Logsdon v. Logsdon, $204 \mathrm{Ky} .104,111,263$ S.W. 728, 731 (1924); Turgeon v. Bean, 109 Me. 189, 194, 83 A. 557, 559 (1912); Jackson City Bank \& Trust Co. v. Fredrick, 271 Mich. 538, 546, 260 N.W. 908, 910 (1935); Morgan v. Fidelity \& Deposit Co., 66 Wash. 649, 653, 120 P. 106, 107 (1912); 49 C.J.S. Judgments § 235 (1947); 46 AM. JuR. 2D Judgments § 681 (1969); RestatzemanT (SkCOND) OF JUDGMENTs \$§ 126-27 (Tent. Draft No. 6, 1979). Cf. 28 U.S.C. \$§ 2241(d), 2255 (1976) (venue provisions for attack on state and federal convictions).

110 See, for instance, the "clean hands" doctrine in child custody litigation. R. Crouch, 
from enforcement because it may properly be invoked by a losing litigant whose only purpose is to complain of defects in the original proceeding. Its primary function is not enforcement of judgments, for unlike courts in other states in which the loser's property is located, appellate courts ordinarily have no enforcement capacity superior to that of lower courts.

That the primary function is not enforcement does not mean that appellate courts will never cooperate with lower courts by reinforcing policies facilitating the lower courts' operations. When an appellate court refuses to address a claim improperly raised below, it implements the lower court's procedural rules. The state procedural ground rule, for instance, serves this function on direct Supreme Court review. Within a unitary court system, too, appellate courts typically cooperate with lower courts in this way. ${ }^{111}$ Yet deference to the lower court's preclusion rules cannot be allowed totally to obliterate the appellate court's reviewing function. This need to preserve the reviewing function suggests different treatment of different sorts of preclusion rules.

Some rules preclude claims from being heard at all in specified circumstances, such as a requirement that objections to service of process be raised before trial. Others preclude relitigation of claims that were in fact addressed. In an appellate structure, there are two reasons for honoring preclusion rules of the first sort, but not the second. First, although the lower court has a legitimate interest in barring relitigation so as to encourage litigants to present their claims as forcefully as possible, appellate courts cannot respect such rules without ceasing to be appellate courts, whose function is, after all, to examine questions already decided. Second, a rule that precludes consideration in the first instance is more likely to be a balanced formulation because it restricts the lower court's own powers. A rule that precludes only reconsideration will have its impact almost solely on the appellate process, and it clearly is not for lower courts to decide whether their decisions will be subject to appellate scrutiny.

Normally, there are adequate safeguards in applying another court's preclusion rules as long as that other court uses the preclu-

supra note 82 , at $24 ;$ S. KATZ, supra note 82 , at 66 .

111 For instance, in the adequate state ground cases, the Supreme Court is bound to no greater extent than the state appellate courts, and if the state court actually addresses the allegedly barred constitutional claim, the Supreme Court may also. See, e.g., Boykin v. Alabama, 395 U.S. 238, 240-41 (1969); Coleman v. Alabama, 377 U.S. 129, 132-33 (1964); Raley v. Ohio, 360 U.S. 423, 436 (1959); Whitney v. California, 274 U.S. 357, 360 (1927). 
sion rules for its own purposes-the "double or nothing" approach. But depending upon the rule's content, this safeguard may not always be sufficient. As a formal matter, a rule that a litigant may only press his claims once applies equally to the first court in the decisionmaking series and to the second court, but the impact is different. In a hierarchical structure in which one court knows that it will always be first, the formal safeguard is transparently useless. Moreover, such a rule cannot prevail in a hierarchical sequence because the purpose of hierarchy is to allow a second look. These arguments do not pertain in a lateral enforcement system because the unavailability of critical scrutiny is not structurally illogical. In evaluating the deference due the first court's preclusion rules, one crucial question will therefore be whether there is any plausible function left for the second court if it is required to adhere to the first court's preclusion rules.

\section{B. Habeas and Federal Common Law}

1. Habeas as a naked jurisdictional grant. Structural analysis seems at first to make a very easy case for federal finality rules for habeas corpus. Like appellate courts, federal habeas courts have no plausible enforcement role; their only conceivable function is some sort of critical scrutiny. Furthermore, it is clear that there must be some function for them to fulfill, because the writ is recognized by the Constitution ${ }^{112}$ and by federal statute. ${ }^{118}$ Finally, the statutory exhaustion requirement ${ }^{114}$ makes literal application of section 1738 and state preclusion rules almost entirely illogical because the case is never ripe for federal scrutiny until the state itself deems the resolution final. ${ }^{115}$ Habeas is similar in this respect to Title VII suits, in which the Court has recognized that a requirement of initial recourse to state administrative agencies makes it structurally illogical to give agency determinations preclusive effect. ${ }^{116}$

112 U.S. ConsT. art. $1, \S 9$, cl. 2.

11328 U.S.C. $\S \S 2241-2255$ (1976). There appears to be no constitutional requirement that federal courts have jurisdiction to issue writs of habeas corpus. Congress had no obligation to grant federal courts jurisdiction to do so, and it was not until 1867 that the extension to state prisoners occurred. See Ex parte Dorr, 44 U.S. (3 How.) 103 (1845); Bator, supra note 48 , at 465 .

11428 U.S.C. \& 2254(b), (c) (1976).

116 Currie, Res Judicata: The Neglected Defense, 45 U. Cm. L. Rzv. 317, 331 (1978). Cf. Hathorn v. Lovorn, $102 \mathrm{~S}$. Ct. 2421 (1982) (relationship between final judgment rule-an exhaustion requirement--and availability of appellate review).

116 Kremer v. Chemical Constr. Corp., 102 S. Ct. 1883, 1891 n.7 (1982); see id. at 1900 
What the statutory and constitutional provisions on habeas most resemble are the various statutory and constitutional provisions that grant jurisdiction without specifying the substantive law. ${ }^{117}$ These "naked jurisdictional grants" include the constitutional provisions on admiralty and controversies between states, ${ }^{118}$ and (perhaps the most famous example) section 301(a) of the Labor-Management Relations Act of 1947,119 which grants district courts jurisdiction over labor disputes. Section 301(a) was upheld in Textile Workers Union v. Lincoln Mills ${ }^{120}$ over constitutional objections that federal question jurisdiction could not be supplied statutorily by a naked jurisdictional grant. Habeas is in a far stronger position because it is explicitly recognized in the Constitution. In addition, a naked jurisdictional grant allows substantial room for incorporation of state finality standards where consistent with federal policies. ${ }^{121}$ The path seems clear, then, for rationalizing the formulation of federal finality rules and the selective disregard of competing state rules.

Lincoln Mills itself, alas, points to a possible flaw in this line of reasoning: the possibility of interpreting the jurisdictional grant as a grant not of power to make common law, but of protective jurisdiction, the power to try cases to ensure that state rules are evenhandedly applied. ${ }^{122}$ For several reasons, protective jurisdiction is an important explanation to consider. First, the Court in Lincoln Mills may have been motivated to reject protective jurisdiction because it exacerbated doubts about the constitutionality of section 301(a); to qualify as federal question jurisdiction, the substantive law apparently should be federal. ${ }^{123}$ Because habeas suffers no comparable potential constitutional infirmities, it could

(Blackmun, J., dissenting).

${ }_{117}$ On these jurisdictional grants generally, see Hart, The Relation Between State and

Federal Law, 54 CoLum. L. REv. 489, 496 (1954).

118 U.S. ConsT. art. III, $\S 2$, para. 1.

11929 U.S.C. $\$ 185$ (1976).

130353 U.S. 448 (1957).

${ }^{121}$ Cf., e.g., Clearfield Trust Co. v. United States, 318 U.S. 363, 367 (1943) (state law may be incorporated into a federal standard where appropriate). This would explain why use of state law is perceived as a matter of comity. See supra notes 83-84 and accompanying text. See generally Monaghan, Foreword: Constitutional Common Law, 89 HARv. L. REv. 1 (1975).

${ }_{122} 353$ U.S. at 460 (Burton, J., concurring); id. at 473-77 (Frankfurter, J., dissenting). See generally Mishkin, The Federal "Question" in the District Courts, 53 Colum. L. REv. 157,184 (1953) (discussing the legitimacy of protective jurisdiction in the federal question area). 165.

12s 353 U.S. at 473-78 (Frankfurter, J., dissenting). See also Mishkin, supra note 122, at 
be construed as a grant of protective jurisdiction without raising constitutional doubts. Habeas arguably is like diversity jurisdiction: a constitutional grant of protective jurisdiction without the power to make common law. ${ }^{124}$ Second, protective jurisdiction is not a structurally illogical function for habeas, because its purpose is neutral factfinding and application of law to facts-functions the district courts are appropriately positioned to fulfill. This seems a particularly plausible function where forfeiture rules rather than rules regulating relitigation are involved, because forfeiture rules are not as obviously suspect as even formally neutral relitigation rules are in a sequential decisionmaking process. ${ }^{125}$

Third, and most important, the protective jurisdiction alternative must be addressed because it entails the use of state forfeiture rules, which is precisely the rendering state model used on direct review under the adequate state ground doctrine in cases of procedural default. Acknowledging that there is a jurisdictional grant does not explain why it should be construed as a choice of federal instead of state finality rules. Lincoln Mills cited federal policies such as the need for uniformity in the law of labor-management relations and for reduction in disruptions from labor-management strife. ${ }^{128}$ The case for federal finality rules in habeas must rest upon comparable federal policies, policies unlikely to be adequately reflected in the rules that states adopt. The question therefore is whether the fact that states formulate forfeiture rules for their own use provides adequate assurance of balanced treatment of the policies disfavoring preclusion, or whether the process of formulation is potentially biased towards premature foreclosure of protected federal claims.

124 See U.S. ConsT. art. III, \& 2, para. 1; 28 U.S.C. $\S 1332$ (1976). On the purposes of diversity jurisdiction, see Erie R.R. Co. v. Tompkins, 304 U.S. 64 (1938) (diversity jurisdiction not a grant of power to make common law); Bank of the United States v. Deveaux, 9 U.S. (5 Cranch) 61, 87 (1809) (Marshall, C.J.) (federal courts given diversity jurisdiction because of apprehension of state court bias).

${ }^{125}$ Rules barring relitigation have their primary impact on subsequent decisionmakers and a comparatively slight limiting effect on the power of the court that considered the matter first. Because states know that they will address the issue first, such rules would be tempting devices for states to use to shield their mistakes from further scrutiny. For an additional reason peculiar to the criminal contert, state prohibitions against relitigation are unlikely to be balanced. Under the double jeopardy clause, U.S. CoNST. amend. V, made applicable to the states in Benton v. Maryland, 395 U.S. 784 (1969), states cannot retry acquitted defendants. Arizona v. Washington, 434 U.S. 497, 503 (1978). Rules allowing reopening of final decisions in criminal cases can therefore only work to the advantage of the accused. The state thus has no incentive to allow relitigation even if an impartial decisionmaker would conclude that it was warranted.

128 353 U.S. at 455. 
2. The inadequacy of protective jurisdiction. The difficulty with a protective jurisdiction theory of habeas is that it possesses all the flaws of the adequate state ground doctrine as applied to state default rules. In particular, there may be no separate body of cases in which the rules are formulated and in which the constitutional issues are not present. For instance, every application of a limitation on the timing of grand jury objections is one in which the state is equally disinclined to allow the defense and thus to frame default rules too strictly. In diversity cases, the federal court uses state rules that were formulated to resolve the claims of nondiverse disputants. Many criminal default rules, by contrast, are narrowly drawn to apply only in constitutionally problematic situations. For this reason, they are not entitled to an irrebuttable presumption of fairness.

The Burger Court is obviously not disposed to assume that state trial courts are prejudiced against the assertion of federal constitutional rights. To the contrary, it has pointed out that state judges are bound by constitutional obligations as much as are federal judges. ${ }^{127}$ But it is one thing to say that state court determinations of fact are presumably accurate and unbiased against federal rights; it is a wholly different matter to say that state legal principles are entitled to a similar presumptive validity. The Burger Court has advanced the first proposition, but neither it nor any previous Court has accepted the second. ${ }^{128}$ Professor Alexander Bickel noted that because state legislators are oath-bound to support the Constitution, and because state judges acting in their common law capacities are bound in addition by the supremacy clause, it is arguably unnecessary for federal courts to review the rules that state authorities formulate. ${ }^{129}$ But as Bickel was well aware, this argument would spell the end of Marbury $v$. Madison ${ }^{130}$ and our entire present system of constitutional adjudication. ${ }^{131}$

${ }^{127}$ U.S. Const. art. VI, para. 2. See, e.g., Allen v. McCurry, 449 U.S. 90, 105 (1980); Stone v. Powell, 428 U.S. 465,493 n.35 (1976).

198 See, e.g., Allen v. McCurry, 449 U.S. at $101 \&$ n.17; Stone v. Powell, 428 U.S. at 493 n.35.

129 A. Bickel, The Least Dangerous Branch 12-13 (1962).

1305 U.S. (1 Cranch) 137 (1803).

131 As Professor Bickel pointed out, Marbury v. Madison implicitly rejected the argument that judicial review was unnecessary because legislators were also bound to adhere to the Constitution. A. BICKBL, supra note 129; - at 8. The argument that state courts are no more likely to err than federal courts is particularly irrelevant when statutory rules bar any state judicial resolution at all. As such cases demonstrate, the focus is necessarily on the preclusion rules and the incentives on those who formulate them, not on the process of the 
Although it may not be obvious why factfinding should be viewed differently from formulation of legal norms, it is clear that the Supreme Court cannot conclusively presume the adequacy of state default norms narrowly tailored to prescribe the forfeiture of federal defenses. To do so would allow a state complete control over a federal policy that works against its own potential self-interest as party to a dispute. ${ }^{132}$ This danger could account for treating waiver of federal criminal defenses as a matter of federal law. ${ }^{132}$ This is not to say that states invariably attempt to cut short the assertion of defendants' federal claims, any more than states invariably adopt unconstitutional substantive law. ${ }^{134}$ It is just that, given the potential for abuse, federal scrutiny must in theory be available. The remaining problem is therefore to explain why there is no such federal scrutiny under the adequate state ground rule-why state default rules are not preempted on direct review when they are preempted on habeas, and when state waiver rules

particular substantive application.

193 It is not merely that the state is a party to the dispute. States are sometimes party to other types of litigation, such as contract disputes, without doubt being cast upon the fairness of the rules employed. What negates any possible inference of unfairness is the rules' generality. They apply to many cases not involving the state as a party, in which the state presumably has no interest but in a fair resolution. Moreover, the state cannot anticipate in advance whether it will appear as a plaintiff or a defendant in such cases. The state thus formulates the rule in a position of reflective equilibrium.

Criminal preclusion rules are different. The claim in Michel v. Louisiana, 350 U.S. 91 (1955), for example, was a constitutional challenge to grand jury discrimination. Louisiana had a special rule regulating the timing of such claims. It is hard to see how a rule so clearly aimed at foreclosing defendants' constitutional rights can be treated as independent of the merits of the federal protection for defendants.

122 The waiver cases have assumed that forfeiture of constitutional rights is a federal issue, because states would otherwise be able effectively to frustrate federal interests. See Boykin v. Alabama, 395 U.S. 238, 243 (1969) ("The question of an effective waiver of federal constitutional rights in a proceeding is, of course, governed by federal standards."); Fay v. Noia, 372 U.S. 391, 439 (1963) ("[W]aiver affecting federal rights is a federal question."). See also Brewer v. Williams, 430 U.S. 387, 403-04 (1977), in which the Court stated:

The District Court and the Court of Appeals were correct in the view that the question of waiver was not a question of historical fact, but one which, in the words of $\mathbf{M r}$. Justice Frankfurter, requires "application of constitutional principles to the facts as found . . . " Brown v. Allen, 344 U.S. 443, 507 (Separate Opinion) . . . The District Court and the Court of Appeals were also correct in their understanding of the proper standard to be applied in determining the question of waiver as a matter of federal constitutional law ....

23 That some procedural limitations may also apply to suppression claims based upon state law provides some safeguard, but even state law suppression claims are antithetical to the state's interests, because the state acts as enforcer of state criminal law. Thus, the fact that the state forecloses such state-created defenses on equal terms with federal defenses is not probative. Conversely, if a federal claim might ordinarily be equally available to aid state interests, then the fact that some procedural limit applied only to burden the exercise of that federal claim would not be fatal. 
are preempted at all stages.

\section{Sufficient Deterrence: Deferred Scrutiny as a Sanction for Pro- cedural Defaults}

An examination of the underlying purposes of default and waiver rules and certain common themes in Warren and Burger Court cases suggests that state default rules are honored on direct review because, unlike waiver rules, they serve legitimate general deterrent purposes. These deterrent purposes result in a windfall to the state that is insulated from federal scrutiny by the legitimacy of the goal of efficient structuring of state criminal processes. Waiver rules serve no general deterrent functions and are therefore preempted at all stages. The protection that default rules receive by virtue of their conduct-structuring function, however, only defers the application of federal standards. On habeas, the fairness of keeping a particular defendant in jail because of his procedural error must be addressed. Habeas looks at the validity of detention simpliciter.

The initial premise in the foregoing argument is that default rules and waiver rules are designed to serve different purposes. Both foreclose the assertion of rights in the immediate case, but default rules also serve a significant general deterrent function unrelated to the instant case, structuring the course of litigation generally and deterring procedural misconduct by others in the future. Examples are contemporaneous objection rules and rules regulating the raising of objections to grand jury composition. In their deterrent capacity, default rules impose forfeitures for conduct that is inimical to the orderly administration of justice, and promote the consideration of federal constitutional claims in the long run. ${ }^{135}$ Thus, default rules focus not only on the individual case, but on the future acts and rights of third parties. Default rules result in forfeitures that may seem unjust in the immediate case, but when this is the case, their purpose in so doing lies elsewhere. Waiver rules serve no such deterrent purpose. Waiver rules providing for forfeiture of claims after a guilty plea or after a grant

1ss See, e.g., Wainwright v. Sykes, 433 U.S. 72, $88-90$ (1977), emphasizing that the purpose of the contemporaneous objection rule is to facilitate just resolution of claims, state and federal, in a single fair proceeding. The paradoxical result is that the federal claim forfeited in Waipwright would never be addressed at all if the procedural bar were given effect, but the long-range purpose was supposedly to maximize fair treatment of Miranda claims generally. In contrast, federal waiver issues involve rules not ostensibly designed to promote consideration of constitutional claims in the long run. 
of permission to search are not based on deterrence, because the state is not trying to deter guilty pleas or consent searches: to the contrary, it actively encourages them. If a waiver is to be justified, it must be on the merits of the immediate case as an appropriate consequence to affix to the relevant act of waiver. Without deterrence as a justification, the state may not impose an arbitrary forfeiture unjustified by the merits of the individual case. ${ }^{188}$ Its interest in arguing that a forfeiture has occurred is in making convictions easier to obtain, not in promoting the orderly presentation of constitutional claims in the long run. This interest in foreclosing constitutional defenses is insufficient to insulate waiver rules on direct review. ${ }^{187}$

The principle that general deterrent policies resulting in a windfall to one of the parties will be treated differently on direct and collateral attack is suggested by Fay $v$. Noia ${ }^{13 s}$ and strikingly affirmed by Stone v. Powell. ${ }^{189}$ Both Fay and Stone made certain arguments unavailable on habeas because there was "sufficient deterrence" in the fact that they were cognizable on direct review. In Fay, the argument was that the defendant had failed to present a constitutional claim in the procedurally appropriate manner. In Stone, it was that the police had failed to observe constitutional limits on procedures for gathering evidence. In both cases, the "sufficient deterrence" distinction between direct review and habeas was based upon objections to granting windfall benefits.

Opponents of the exclusionary rule have long been bothered that exclusion operates as a windfall for the defendant: the prisoner goes free because the constable has blundered. ${ }^{140}$ The incarceration of criminals should not depend upon such procedural technicalities. Unless the technicality is related to the merits of continued incarceration, it seems arbitrary to decide cases upon such grounds. The Stone majority believed that a trial untainted

136 A seeming exception to this analysis, Illinois v. Allen, 397 U.S. 337 (1970), involved waiver of the right to be present at trial because of the defendant's contumacious courtroom conduct. Although deterrence was a reason for imposing a forfeiture, specific rather than general deterrence was sought, and not mere imposition of an arbitrary sanction to deter conduct by third parties.

${ }^{137}$ This also explains why ad hoc application of a default rule renders a forfeiture examinable on direct review even though defaults generally are not scrutinized at that stage. Because novel or arbitrary applications are unpredictable, they are rarely an effective deterrent strategy. Thus, ad hoc application suggests a foreclosure motivation rather than an interest in deterring procedural misconduct inimical to the administration of justice.

138 372 U.S. 391 (1963).

13. 428 U.S. 465 (1976).

140 People v. Defore, 242 N.Y. 13, 21, 150 N.E. 585, 587 (1926) (Cardozo, J.). 
by illegally seized evidence is not a personal constitutional right and thus is unrelated to the merits of continued incarceration, because the purpose of the exclusionary rule is to deter illegal police conduct. ${ }^{111}$ In effect, the Stone majority held that a purely deterrent policy, with a justification extraneous to the merits of the particular case, will be honored on direct review but not on habeas.

The same sentiment underlies the unwillingness to allow defendants to languish in jail because of their procedural irregularities-a windfall for the state. The Warren Court was disturbed in Fay by the anomaly of keeping one prisoner in jail because of a procedural forfeiture while allowing another identically situated to go free. ${ }^{122}$ Because most procedural rules are designed to structure the course of litigation generally rather than to affix just resolutions to particular cases, such differentiations seem unacceptable. The sanction of forfeiture, which may result in the loss of a constitutional defense, is not proportioned to the gravity of the defendant's disobedience of the procedural rule, just as the sanction of exclusion, which may result in acquittal or dismissal, is not proportioned to the gravity of the particular fourth amendment violation. In ways the Warren Court probably could not have understood or anticipated, its innovative distinction between direct review and collateral attack in Fay v. Noia was the precursor of the "sufficient deterrence" jurisprudence of Stone v. Powell.143

Once general deterrent justifications are exhausted, state default rules are in essentially the same position as waiver rules. The state's claim that forfeiture of the federal claim is warranted, and that continued incarceration without a chance for retrial is an appropriate sanction, must then be evaluated according to a federal standard. ${ }^{144}$ What that standard should be is beyond this article's purpose, which is to address the consistencies between the Warren and Burger Courts' pattern of choice between state and federal forfeiture standards. The obvious difference between the two Courts'

341428 U.S. at 486.

162372 U.S. at 441.

${ }^{243}$ See also United States v. Calandra, 414 U.S. 338, 351 (1974) (use of illegally seized evidence in grand jury proceedings permitted on sufficient deterrence theory); United States v. Janis, 428 U.S. 433, 453-54 (1976) (use of evidence illegally seized by the state permitted in federal civil proceeding on sufficient deterrence theory).

24t It is suggestive of the convergence that in addressing the effect of a state default rule on habeas, the Fay court relied on Johnson $v$. Zerbst, a federal waiver case, for its standard of relinquishment. Fay v. Noia, 372 U.S. 391, 438-39 (1963) (citing Johnson v. Zerbst, 304 U.S. 458 (1938)) (enunciating the deliberate bypass standard for habeas consideration of procedural defaults). See also Francis v. Henderson, 425 U.S. 536, 548 n.2 (1976) (Brennan, J, dissenting). 
approaches, despite their common choice of federal rules, is how strict the federal standard ought to be.

Nevertheless, a few tentative observations are suggested by the analogy of Fay to Stone. First, it may be important whether the procedural irregularity was an innocent and somewhat technical mistake or a deliberate flouting of proper procedures. The Warren Court was relatively willing to characterize defense mistakes as innocent; the Burger Court sees them as likely sandbagging, but views hypertechnical police violations of the fourth amendment benignly. ${ }^{145}$ Both Courts consider the willfulness of the conduct in assessing the limits of just retribution on habeas. Thus the Fay Court spoke in terms of "deliberate bypass," and the Wainwright Court asked the defendant to demonstrate "cause."

The Wainwright Court also spoke in terms of "prejudice." $\mathbf{A}$ prejudice test seems calculated to assess whether the result should have been different if the constitutional claim had not been forfeited. Its contours are not yet clear, ${ }^{148}$ but it bears some resemblance to the issue of whether the sanction is a windfall. This may mean either that the forfeited defense relates to guilt or innocence, or that it would have changed the resulting verdict at the initial trial. A constitutional right to an acquittal need not be based upon factual innocence, for "guilt" is also a matter of constitutionally satisfactory proof. ${ }^{147}$ These questions call for further exegesis, for

145 The Supreme Court has suggested on many occasions that a good-faith exception to the exclusionary rule might be warranted because there would be no useful deterrent purpose to applying it in such cases, see, e.g., Michigan v. DeFillippo, 443 U.S. 31,38 n.3 (1979); Stone v. Powell, 428 U.S. 465, 540 (1976) (White, J., dissenting); Brown v. Illinois, 422 U.S. 590, 611-12 (1975) (Powell, J., concurring); United States v. Peltier, 422 U.S. 531, 536-38 (1975); Michigan v. Tucker, 417 U.S. 433, 447 (1974). The Fifth Circuit has adopted a goodfaith exception, see United States v. Williams, 622 F.2d 830 (5th Cir. 1980) (en banc), but to date the Supreme Court has declined to do so, see Taylor v. Alabama, 102 S. Ct. 2664, 2669 (1982).

When put in a different context-the legal effect of procedural default by defense attorneys-Justices Brennan and Marshall agreed that forgiveness of innocent errors would not undercut the deterrent effect of rules excluding constitutional objections. Wainwright v. Sykes, 433 U.S. 72, 113 (1977) (Brennan, J., joined by Marshall, J., dissenting). Stressing that technical difficulty of the issues and attorney inadvertence, not deliberate "sandbagging," were responsible for most procedural defaults, id. at 103-04, they argued that the attempt at deterrence was "senseless" for three reasons: "unplanned and unintentional action of any kind generally is not subject to deterrence"; loss of the claim at trial is sufficient deterrence; and keeping the habeas petitioner in jail is not an appropriate penalty. Id. at 113. Of course, the conservatives had for years been talking about sufficient deterrence of police misconduct and of punishing the public at large for the constable's blunders.

14" See United States v. Frady, 102 S. Ct. 1584 (1982); Engle v. Isaac, 102 S. Ct. 1558 (1982).

147 In his fascinating critique, Professor Seidman argues that one continuity between the Warren and Burger Courts is their desire to use the criminal process for broad social 
the determination of whether custody is "in violation" of the Constitution $^{148}$ is obviously not easy.

\section{Conclusion}

The Warren and Burger Courts' changing estimations of general deterrence and individual fairness have not altered the pattern of choice between federal and state preclusion rules the Warren Court inherited in 1953, except for the early demise of the adequate state ground rule on collateral attack in Fay $v$. Noia. Other than that early deference, habeas has consistently been governed by federal preclusion rules and it is unlikely that the Burger Court will turn back the clock in this regard. ${ }^{149}$ Waiver has been treated as a federal issue on direct and collateral attack and in the state courts themselves. State procedural defaults are reviewed only for evenhandedness and consistency with due process on direct attack, and are then judged by federal preemption standards on collateral attack.

As this article has shown, three premises generate this peculiar structure. First, states cannot be given complete authority to devise rules to make convictions easier at trial through forfeiture of constitutional claims unique to defendants. Their self-interest is too transparent. Second, some system of sanctions for violation of reasonable procedural rules must be established by the states and respected by federal courts. Finally, the constitutional and statutory grant of jurisdiction to federal habeas courts allows those

purposes rather than for accurate determination of guilt or innocence. Seidman, supra note 2, at 467. Seidman seems to find this emphasis inapt and the Burger Court's proclamation of interest in guilt or innocence hypocritical. I agree with his thesis that both Courts use the rules governing procedural defaults for broader deterrent purposes, but disagree with his conclusion that this is undesirable. Seidman apparently lumps together all procedural rules that are unrelated to guilt or innocence, denigrating them as collateral to the proper truthseeking function of the courts, whereas the Burger Court seems to be striving, however clumsily, to distinguish "personal" constitutional rights such as double jeopardy from "purely deterrent" ones. See, e.g., Stone v. Powell, 428 U.S. 465, 486 (1976). Thus cases such as Rose v. Mitchell, 443 U.S. 545 (1979) (habeas available to enforce the right to indictment by a grand jury chosen by racially nondiscriminatory methods), and Blackledge v. Perry, 417 U.S. 21 (1974) (habeas available to enforce the right to de novo state trial without incurring heavier punishment in the second proceeding), may not be inconsistent in theory with Stone v. Powell, 428 U.S. 465 (1976) (habeas unavailable to relitigate suppression claims under the fourth amendment exclusionary rule). My references to the legality of continued incarceration include all unexcused violations of personal constitutional rights, not just those dealing with factual guilt, without taking a position on what rights are personal and what rights are not.

${ }^{148} 28$ U.S.C. \& $2254(\mathrm{a})$ (1976).

149 See Hill, supra note 92 , at 1074. 
courts a critical reviewing function to protect against incarcerations resulting from technically correct and evenhanded applications of state law that actually deny federal constitutional rights. 